\title{
THE EFFECT OF EDUCATION CERTIFICATION ON PROFESSIONALISM OF CHRISTIAN EDUCATION TEACHERS
}

\author{
Purnama Pasande ${ }^{1}$, Elsye Evasolina Tulaka ${ }^{2}$, Ezra Tari ${ }^{3}$ \\ ${ }^{1,2}$ Sekolah Tinggi Teologi Sta'rs Lub Luwuk Banggai, Sulawesi Tengah, Indonesia \\ ${ }^{3}$ Sekolah Tinggi Agama Kristen Negeri Kupang \\ ${ }^{1}$ purnama.pasande@gmail.com. ${ }^{2}$ evalinatulaka@gmail.com ${ }^{3}$ tariezra@gmail.com.
}

\begin{abstract}
One of the effort to improve teacher professionalism requires certification to improve the proficiency and quality of teachers in implementing the teaching and learning process. In essence, certification and teacher competency standards are to get good and professional teachers. Having competence to carry out the functions and objectives of the school in particular, as well as educational goals in general, according to the needs of society and the demands of the times. The type of this research is quantitative research with survey methods. Christian Education (PAK) teachers who already have certification will have a significant influence on the work professionalism of Christian Education (PAK) teachers in carrying out their duties and responsibilities as a religious educator.
\end{abstract}

Keywords : Certification, teachers, Christian Education, professionals

\section{INTRODUCATION}

Teacher competencies as referred to in Article 8 of the Teacher and Lecturer Law cover pedagogical, personal, social and professional competencies. Educator certificates are given to teachers who have met the requirements of both academic qualifications and competencies. Yamin said that "certification is the process of providing educator certification for teachers and lecturers or formal evidence as recognition given to teachers and lecturers as professionals (Yamin, 2006). Teacher certification as an effort to improve teacher quality is accompanied by an increase in teacher welfare, so that it is expected to be able to continuously improve the quality of learning and the quality of education in Indonesia. The form of teacher welfare improvement is in the form of providing professional allowances for one-time base salary to teachers who have an educator certificate. The allowance applies to all teachers, both teachers who are civil servants (PNS) and teachers who are non-civil servant (private) (Jalal, 2007).

The success of learning activities in schools will be achieved if all the elements involved in it can work together or become a solid work team to achieve school goals. The quality of learning is strongly influenced by the professional quality of principals and teacher performance. "Increasing professional skills will be more successful if done by the principal and teachers with their own volition and effort. But often the teacher still needs the help of 
others, because he does not know or do not understand the types, procedures and mechanisms to obtain various sources that are very necessary in an effort to improve their professional abilities (Sagala, 2009). Seeing the above phenomenon, the authors feel the need of conducting research to find out how much certification educators and academic supervision have an influence on the professionalism of Christian Educationteachers.

\section{METHODOLOGY}

The research method used in writing this article is a qualitative research method. Where the qualitative method is descriptive analysis (Tari, 2018). Talizaro Tafonao cites the opinion of Sugiyono, saying that qualitative research methods can be interpreted as research methods used to examine the condition of scientific objects, where researchers act as key instruments, data collection techniques are carried out by triangulation (combined). Sources of data used in qualitative research are natural environments (Tafona'o, 2019).

\section{RESULTS AND DISCUSSION}

\section{Professionalism and Certification in Biblical View}

Referring to each understanding that professionalism and certification must be clear, so that it can be a benchmark in determining the biblical foundation, although in the concept explicitly by giving an overview of the actions, teachings and competencies possessed by Bible characters.

Professionalism comes from the word profession according to Kunandar is "a job or position that requires certain expertise" (Kunandar, 2007). Then, also the teaching profession is a special expertise and authority in the fields of education, teaching and training that are occupied to become a livelihood in meeting one's life needs (Kunandar, 2007). While professionalism, Arifin explained that, "A view that a certain expertise is needed in certain jobs, which expertise was obtained through special education or special training" (Arifin, 2007). Professionals are work or activities carried out by a person and become a source of income for his life that requires expertise, or skills that meet certain quality standards or norms, and require professional education (Arifin, 2007). Kunandar said that professional teachers are well-educated and well-trained people with rich experience in their fields (Kunandar, 2007).

Then certification in the concept of understanding that in this case is explained as "a sign or letter (statement) written or printed from an authorized person that can be used as proof 
of ownership of an event". This means that someone who has been considered a professional in the field of learning, especially Christian Education, is given an award or a legal acknowledgment by the government, by providing an additional one-time salary, thereby increasing the income of a Christian Education teacher.

So it can be concluded that professionalism is a special skill possessed by someone, especially in this case is a teacher. Then certification is an award given based on their competencies, then academic supervision is a series of activities that can help teachers develop their expertise or competencies.

\section{Educators in the Old Testament}

The Bible teaches about God as a great educator who thoroughly shows that God as an educator. This fact is evident in God's command to educate people to get to know God and His will in order to make human life better (Deut. 6: 1-3a). From the beginning, God stated that God's people must be taught and nurtured in terms of daily life such as worship, household life, community life and relationships between individuals, then values and norms. Norman E. Thomas said that, "God has no hands but our hands to do the work now, He does not have our feet to guide people to His path, He has no mouth but our mouth to tell people about what His want (Thomas, 2000).

From the verses above, it can be said that God is a Teacher who is always loyal to His people. Therefore, God also hopes that His people will also remain faithful and obedient to Him. In His teaching God uses various methods that lead to His professional level as an educator, such as:

First, Exams. God tests to find out man's obedience to Him. As God did with Adam and Eve in the form of a prohibition on eating fruit from the tree of the knowledge of good and evil (Gen. 2: 16-17), so also was God's test with Abraham to offer Isaac as a burnt sacrifice (Gen. 22: 1-19), and God's test to Job about his loyalty to God (Job 1-10).

Second. Guidance. God instructs people about what they have to do in their life journey. For example, instructions to Noah to make the ark (Gen. 6: 15-16), and instructions for building the tabernacle (Ex. 25).

Third, Discipline. God gave laws for His people as a guidelines or directive for their lives, for example the Ten Commandments. Even when humans fall into sin God judges His people. Judgment is in the form of a situation where a man or woman must live in a world that has been colored by sin and fall. 


\section{Educators in the New Testament}

Jesus is called the Savior, Redeemer and Deliverer. And besides that Jesus is also the Great Teacher. His expertise as a teacher is generally heeded and praised by the Jewish people, which is why they call Him a "Rabbi". Because He taught them as powerful men, unlike the scribes who used to teach them (Matt. 7:29). In the four Gospels, several times the word teaching is found in the story of Jesus' ministry. That means teaching is a very important part of Jesus' ministry. He taught in the temple, in the synagogue, on the beach, in the lake, or in the fishing boat, in the hills and in a level place. He teaches anywhere (Boehlke, 2009). So Jesus' professionalism is seen in what He does in the ministry, especially teaching. He taught professionally by mastering every subject he taught, as in Matthew 5 about the Sermon on the Mount, then Jesus also healed the sick.

\section{Christian Education Teacher Professionalism}

Then in the Educational Encyclopedia, Soeganda Poerbakawadja and H. A. H. Harahap explained,

An educator is a person who gives or carries out educational tasks, duties to educate. In everyday life people often say "he is an educator". What is meant is usually "an education expert, or a good educator". Educator titles are also usually addressed to parents, teachers and religious leaders who succeed in their educational endeavors. Parents as educators in the family educate on the basis of blood relations, while teachers and religious leaders educate on the basis of his position or office (Poerbakawadja, n.d.).

From the above understanding according to Poerkawadja and Harahap, the teacher in his role has a broad scope, which includes; teaching, training and educating. A teacher has a calling and responsibility to be able to play a role for others, both in the family, community and in all aspects of life. Even teachers are seen as the main forming figures for prospective citizens (Boehlke, 2009). That means that the teacher has an important role in society, both through knowledge and by example in action. Thus the teacher plays a role in life not only through speech or teaching but also in terms of real actions in everyday life.

The new national education paradigm places educators as professionals who are tasked with planning and implementing the learning process, assessing learning outcomes, conducting mentoring and training, and conducting research and community service, especially for 
educators at tertiary institutions (Arifin, 2007). Kunandar said that professional teachers are well-educated and well-trained people with rich experience in their fields (Kunandar, 2007).

In the Law on Teachers and Lecturers Chapter 1 Article 1 Paragraph 1, explained that, "The teacher is a professional educator with the main task of educating, teaching, guiding, directing, training, assessing and evaluating students in early childhood education formal education path, primary and secondary education (Kunandar, 2007).

So it can be concluded that professionalism is an area of ability possessed by someone in the duties and responsibilities they do, especially teachers in carrying out their duties as educators, means the area of expertise they have. Related to that, it can also be said that the professionalism of Christian Education teachers is the expertise of a Christian Education teacher in the religious field which is evident from the nature and actions that continually develop themselves so that they have the knowledge and skills that support them in carrying out their duties and responsibilities as Christian Education educators.

\title{
Overview of Christian Education Teacher Professionalism
}

\begin{abstract}
Sudarwan Danim said that,
Professionalism comes from the English word professionalism which classically means professionalism. Professional people have different characteristics and attitudes than unprofessional people, even if they do the same work or say they are in one workspace. It is not uncommon for people with the same educational background and work in the same place to display different professional performances, as well as differing public recognition of them (Danim, 2010).
\end{abstract}

Future teachers appear as instructors (teachers), whose function has been prominent so far, but has shifted as a coach, counselor, and learning manager. As a coach, the teacher will act like a sports coach. It encourages students to master learning, motivate students to work hard and achieve the highest achievements, and help students appreciate the value of learning and knowledge. As a mentor or counselor, the teacher will act as a friend of students, be an example in a person that invites respect and intimacy from students. As a learning manager, the teacher will guide students to learn, take initiatives, and come up with good ideas they have (Danim, 2010).

\section{The Call of Christian EducationTeacher}


The tasks and calls of Christian Education teachers are an important key in implementing education. If the discussion is focused on the role of teachers in improving the quality of education in schools, here are some principles for seeing teachers in their assignments and vocations, namely;

First, understand his task as God's calling (cf. Ephesians 2:10). It means "God's fellow worker" in equipping others. In the world of education and teaching through schools not because there are no other occupations, or because they are urged by the motto "for the sake of survival" (survival for living). A teacher develops feelings and beliefs called to be educators and teachers. There is clarity this call must still make tough in the middle of this life journey.

Second, develop true identity (self concept). A good teacher always learns to accept him and be able to appreciate him for who he is. Don't try to be someone else. Be yourself! (Danim, 2010). Every person God creates and designs are unique. Healthy self-concept selfacceptance and appreciation from the teacher will have an impact on their students, directly or indirectly. Teachers with positive self-concepts are not ashamed to admit their weaknesses in front of others, including in front of their students. Nobody is perfect. Teachers with healthy self-concepts value the views of their students even if they are not satisfactory. He tried to understand their feelings (empathy) (Sinamo, 2005).

Third, develop their knowledge. There are many ways we develop knowledge. First of all, of course, diligently reading the literature. Also diligently practicing problem solving lessons. The obstacle in this case is often whether or not supporting facilities such as school libraries are available for teacher needs. In addition, the teacher's will (personal will) to provide learning time in addition to various other activities. Jansen Sinamo said that, "in my opinion, a teacher who has a vocation implanted in his heart:" I equip myself to equip the students whom God entrusts me to serve "(Sinamo, 2005). Life becomes meaningful when it is used to serve others.

Fourth, improve the quality of service in terms of educating, guiding and teaching. The task of the teacher is not just teaching subjects to students. He was not only present in his class to tell stories, give lectures, give examples of questions to be worked on together (Sinamo, 2005).

\section{Christian Education Teacher Competencies}

Competency is defined in various ways, but basically competence is a roundness of mastery of knowledge, skills, and attitudes displayed through performance, which is expected 
to be achieved by someone after completing an educational program. According to the Big Indonesian Dictionary (KBBI), "competence is an authority (power) to determine or decide something. Not excessive if said that competence is an absolute requirement that must be possessed by an educator. Then "competence is the mastery of a task, skill, attitude and appreciation needed to support success (Mulyasa, 2011). Then Sudarwan Danim said,

Competence is a set of knowledge, skills and basic values that are reflected in the habits of thinking and acting of a professional. Competence can also be defined as a specification of the knowledge, skills and attitudes that a person has and their application in work, in accordance with the performance standards required by the community and the world of work (Danim, 2011).

From some of the opinions above, in short that competence is knowledge, skills and abilities that are controlled by someone who has become a part of himself, so he can perform cognitive, affective and psychomotor behavior as well as possible. So teacher competence can be interpreted as an ability and authority of teachers in carrying out their teacher profession.

This can also be based on UU No. 14 of 2005, which explains that teachers and lecturers are special fields of work carried out based on principles and one of them is competency. Then in PP No 74 of 2008, in Chapter 2 article 2, explains that one of the obligations of a teacher is to have competence.

So competence is a requirement for an educator that he must have to be developed, or in other words a teacher must have competence (a set of basic abilities that must be possessed). Teachers as learning agents, especially Christian Education teachers are expected to have competence that supports the expected performance.

Andar Gultom stressed,

Christian Education Teacher competency standards are useful to be a benchmark for all interested parties in the field of Christian Education in the context of fostering, enhancing the quality and career paths of Christian Education teachers, and increasing the performance of Christian Education teachers in the form of creativity, innovation, skills, independence, and responsibility in accordance with his professional position (Gultom, 2007).

Teacher competency standards become a visible measure to assess the level of professionalism so as to achieve good performance. Pedagogical competence is related to the management of learning programs, because it includes the ability to elaborate students' abilities, plan learning programs, implement learning programs, and evaluate learning programs (Wahidmurni; Alfin Mustikawan dan Ali Ridho, 2010). In this case the teacher 
facilitates students to realize their potential as the demands of national education competency standards. In this pedagogic competency, a teacher is required to be able to do two important parts which are indicators of the success of this pedagogic competency, namely:

First, Able to Master the Characteristics of Students. In carrying out learning activities, a teacher must understand and comprehend the character of students, that not all students have the same ability and concentration when receiving lessons. Pedagogic relates to the concept of mastery of teaching material in delivering subject matter, teachers need to understand and recognize the characteristics of their students, so that the delivery of material can be adapted to the circumstancesand conditions of students. The competency of every Christian Education teacher will show the true quality of Christian Education teachers. That competence will manifest in the form of mastery of knowledge, from professional actions and in carrying out its function as a Christian Education teacher (Gultom, 2007).

The Christian Education teacher must emphasize that pedagogically, he must master the concept of learning Christianity well, not just teaching, but there are goals to be achieved. Christian Education learning must have goals that lead to the transformation of faith. The highest goal in Christian Education is to bring students to experience encounter with Christ (Nainggolan, 2007). This becomes a reference for Christian Education teachers that not only equips students with Christian cognitive learning material, but how teachers bring students to experience encounter with Christ, and even make Christ the foremost in their lives.

Pedagogically, a teacher must be able to create a conducive atmosphere for students, so that the implementation of learning activities can run well. This is also a reference for Christian Education teachers, that before carrying out teaching and learning activities, what must be considered is to pay attention to the class atmosphere, including the readiness of the teacher and students. The teacher must be able to create a conducive atmosphere so that the subject matter will always be interesting and not boring. The teacher should have a high sensitivity to quickly find out whether the learning activities have been boring students (Karli, 2007).

Second, Able to Carry out Educational Activities that Educate. Teachers must be able to compile and implement learning designs that educate in full. The teacher is able to carry out learning activities that fit the needs of students.

So a Christian Education teacher, in proving his pedagogical competence, must be able to master the characteristics of a student in the sense that students can follow and obey what has been taught by the Christian Education teacher because they have built an approach that is patterned on the formation of student characteristics, then in the teaching and learning process 
, Christian Education teacher must be able to carry out educational activities so that students grow into a person who is in accordance with the Word of God, through the ability to communicate well and build for students.

Chaerul R explained,

Whether or not a person's image is determined by his personality, especially for a teacher. This personality problem becomes a very important competency which is the basis of other teacher competencies. The teacher's personality determines the success of education. Personality will also be a determinant of whether a teacher will be a good educator and coach, or even as a destroyer for the future of students, especially for students who are in their infancy (primary and secondary school) (Rochman, 2011).

Then according to Alexander Meikel John as quoted by Isjoni that no one can be a true teacher (noble) unless he makes himself a part of students who try to understand all the characteristics of students and their words (Isjoni, 2007). So it can be understood that if the teacher can explore the souls of students, and recognize, know and understand various problems that are being experienced by them, both in terms of learning difficulties and other difficulties outside of learning that can hinder their learning activities, then the teacher will liked by students.

For students teachers are perfect figures, because the teacher's personality has a very large contribution to the success of education, especially in learning. The teacher's personality is also very instrumental in shaping the student's personality (Mulyasa, 2011). This is certainly very understandable, because humans are creatures who like to imitate, including students who imitate the personality of their teacher in shaping his own personality. Therefore teachers still have good personal control so that it gives a positive impact on their students. Therefore, a Christian Education teacher can achieve good personality competence by showing the following indicators;

First, Being Able To Be A Good Example. The Christian Education teacher must build a Christian person within himself, so that he can be a good example in the words, actions and deeds as a teacher and educator. A Christian Education teacher must be able to set an example or model that is seen by everyone including the students themselves. A Christian Education teacher must heed and love his students as an individual who needs a change in himself. But ironically today there are still many Christian teachers who do not respect children and do not love them. 
It is clear that in relation to a Christian Education teacher who must have personality competence must highlight in a good and stable attitude, especially loving oneself and fellow students. In the sense of being able to condition the situation by not mixing personal issues with the work of his profession, and his personality must be able to be a good example.

Second, Loyalty Carries Out The Task. Loyalty is an attitude that cannot be absent in an educator and teacher. This must be a part of the personal competence of a Christian Education teacher, because not only is a teacher able to teach and educate well, but he is also required to perform tasks with full loyalty. Loyalty becomes part of the attitude which also includes when a Christian Education teacher is faithfully listening to his students in expressing their opinions or expressions. "The Christian Education teacher should be able to find a good position to be faithful in teaching and always be in a good situation, and he is ready to be a good listener to his students (Tong, 1991). A good teacher will teach not with harshness or a loud voice, but rather with authority, it means that Christian Education teachers show loyalty in listening, teaching, educating and perseverance as well as patience in carrying out their duties and responsibilities as a Christian Educationteacher, so that in carrying out the vision and mission achieved and will give a positive impression for their students.

Third, Maturity In Attitude. Maturity of life is a real action through the pattern of life every day, this is part of the personal competence of a Christian Education educator or teacher. The start point for a PAK teacher is the awareness of a personal call to be an educator to deliver God's Word so that children experience an encounter with God, so that the goals in Christian Education learning can be realized. Christian Education teachers must have mature personalities, be ready to listen to students, have a commitment focused on shaping the character of students into adults in Christ. Personal qualities of a Christian educator or teacher according to Samuel Sidjabat, there are four things namely:

First, understand that his calling to be a teacher is a gift from God (Ephesians 4: 11-12, Romans 12: 7). God calls believers to be teachers who will carry out the task. Every Christian teacher needs to see and believe that teacher assignments and vocations are golden opportunities to channel God's blessings on others. Second, having and maintaining a commitment (surrender) life to Jesus Christ which is central in the faith journey of every believer. The teacher needs to have a clear commitment to life, which is to live for Jesus (Philippians 1: 21-22; 3:10; 4:13). Third, always strive to improve their knowledge and teaching skills on the basis of honest motivation and commitment to life to God, and fourth always realize that teaching is a technique that needs continuous improvement in developing teacher professionalism (Sidjabat, 1994). 


\section{CONCLUSION}

So it can be concluded that a Christian Educationteacher must reflect a mature personality in the sense of being aware of his calling as an educator, having commitment or submitting himself to the power and authority of God as a Great Teacher, having honest motivation and living in loving God and striving to continue to improve professionalism his teacher The main thing that must be in the person of a Christian teacher is to humble himself under God's authority. Christian Education teacher authority needs to be sourced from God. If he puts himself under authority and under the auspices of God's love, that love will color his life (John 8:32).

\section{REFERENCE}

Arifin, A. (2007). Profil Baru Guru dan Dosen Indonesia. Jakarta: Pustaka Indonesia.

Boehlke, R. R. (2009). Sejarah Perkembangan Pikiran dan Praktek Pendidikan Agama Kristen: dari Plato sampai Ignatius Loyola. Jakarta: BPK Gunung Mulia.

Danim, S. (2010). Profesionalisasi dan Etika Profesi Guru. Yogyakarta: Pustaka Winarsari.

Danim, S. (2011). Pengembangan Profesi Guru. Jakarta: Kencana Prenada Media Group.

Gultom, A. (2007). Profesionalisme: Standar Kompetensi dan Pengembangan Profesi Guru $P A K$. Bandung: Bina Media Informasi.

Isjoni. (2007). Dilema Guru ketika Pengabdian Menuai Kritikan. Bandung: Alfabeta.

Jalal, F. (2007). Pembinaan dan Pengembangan Sertifikasi Guru. Jakarta: Direktorat Profesi Pendidik Direktorat Jenderal Peningkatan Mutu Pendidik dna Tenaga Kependidikan Departemen Pendidikan Nasional.

Karli, H. (2007). Head, Hand, Heart: 3 H dalam KBK. Bandung: Bina Media Informasi.

Kunandar. (2007). Guru Profesional: Implementasi Kurikulum Tingkat Satuan Pendidikan (KTSP) dan persiapan Menghadapi Sertifikasi Guru. Jakarta: Raja Grafindo Persada.

Mulyasa. (2011). Standar Kompetensi dan Sertifikasi Guru. Bandung: Remaja Rosdakarya.

Nainggolan, J. M. (2007). Menjadi Guru Agama: Suatu Upaya Peningkatan Mutu dan Kualitas Profesi Keguruan. Bandung: Generasi Info Media.

Poerbakawadja, S. dan H. A. H. H. (n.d.). Ensiklopedi Pendidikan. Jakarta: Gunung Agung.

Rochman, C. dan H. G. (2011). Pengembangan Kompetensi Kepribadian Guru. Bandung: Nuansa Cendekia.

Sagala, S. (2009). Kemampuan Profesional Guru dan Tenaga Kependidikan. Bandung: Alfabeta.

Sidjabat, S. (1994). Strategi Pendidikan Kristen: Suatu Tinjauan Teologis Filosofis. 
Yogyakarta: ANDI Offset.

Sinamo, J. (2005). 8 Etos Kerja Profesional. Jakarta: Institut Darma Mahardika.

Tafona'o, T. (2019). KEPRIBADIAN GURU KRISTEN DALAM PERSPEKTIF 1

TIMOTIUS 4:11-16 | Tafona'o | Evangelikal: Jurnal Teologi Injili dan Pembinaan Warga Jemaat. Retrieved April 26, 2019, from Evangelikal: Jurnal Teologi Injili dan Pembinaan Warga Jemaat Volume 3, Nomor 1 website: https://journal.sttsimpson.ac.id/index.php/EJTI/article/view/115/pdf

Tari, E. (2018). Teologi Tongkonan: Berteologi dalam Konteks Budaya Toraja (Vol. 2). Retrieved from http://www.stttorsina.ac.id/jurnal/index.php/epigraphe

Thomas, N. E. (2000). Transformasi Misi Kristen: Teks-Teks Klasik tentang Misi dan Kerkistenan Sedunia. Jakarta: BPK Gunung Mulia.

Tong, S. (1991). Arsitek Jiwa. Jakarta: Lembaga Reformed Injili Indonesia.

Wahidmurni; Alfin Mustikawan dan Ali Ridho. (2010). Evaluasi Pembelajaran Kompetensi dan Praktik. Yogyakarta: Nuha Lietra.

Yamin, M. (2006). Sertifikasi Profesi Keguruan di Indonesia. Jakarta: Gaung Persada. 